\title{
STRUCTURE OF FINANCIAL SYSTEMS AND THEIR EFFECTS ON ECONOMIC DEVELOPMENT
}

\author{
Ojesh Vyas ${ }^{1}$, Akshay Kapoor ${ }^{2}$, Abhishek Kadu ${ }^{3}$ and Shivam $\mathrm{Jha}^{4}$ \\ ${ }^{1,2,3,4}$ Student Final year Information Technology, SVKM's NMIMS MPSTME
}

DOI: 10.46609/IJSSER.2020.v05i11.009 URL: https://doi.org/10.46609/IJSSER.2020.v05i11.009

\begin{abstract}
This research aims to analyse the impact of financial system's development and stability on economic growth. There is enough economic literature which defines well-functioning of financial system which helps to gain economic efficiency, investment and growth. It also ventures to study the relationship between the financial development and growth regarding to Indian economy. The following study findings are put to the test:

1. The dependency between financial system and rise in economy.

2. Having large financial system does not mean to rise in economy and GDP of country.

This paper also emphasis on financial deepening of markets in India and other Asia pacific wealth which is generally consider as a critical enabler of economic development. The vast structure of financial system and deepening of financial system gave more access to productive investment to occur. Financial intermediation plays a vital role to improve efficiency and reaching higher real growth in country's wealth. Increase in diversification of financial system with a mixture of small- and large-scale institutions and combination of bank and non- financial institutions will be better suited to real economic needs. However, there are many challenges faced by financial sector in form of Non- Performing Assets (NPAs) of the financial institutions i.e. banks and under developed corporate bond markets. These challenges require some attention and policy amendments.
\end{abstract}

Keywords: Financial System, Financial Deepening, Non-performing Assets, GDP, Financial Intermediation, Corporate Bond Markets.

\subsection{Introduction}

There are several variables which can be dealt with as factors in determining economic development. One such factor is the financial system. The financial system is a methodology of flowing of money i.e. borrowing and lending of funds or as per the demand for and supply of funds to individuals, institutions, MNCs by government. A financial system organizes the flow 
of money and connects surplus funds and deficient funds and facilitates them with necessary assets for better production, hence stimulating the wealth creation which in effect regulates the rate and efficiency of GDP growth. Several institutions, markets, laws, practices, wealth/fund manager, analyst, liabilities, transaction and claims combine construct a financial system. All financial systems incorporate intermediation based on markets and banks. While studying the structural model it concludes that both development and stability of financial sector has positive impact on the economic development of country. Financial stability depends extensively on how vigorous the market and infrastructure is, which construct a financial system.[5][6]

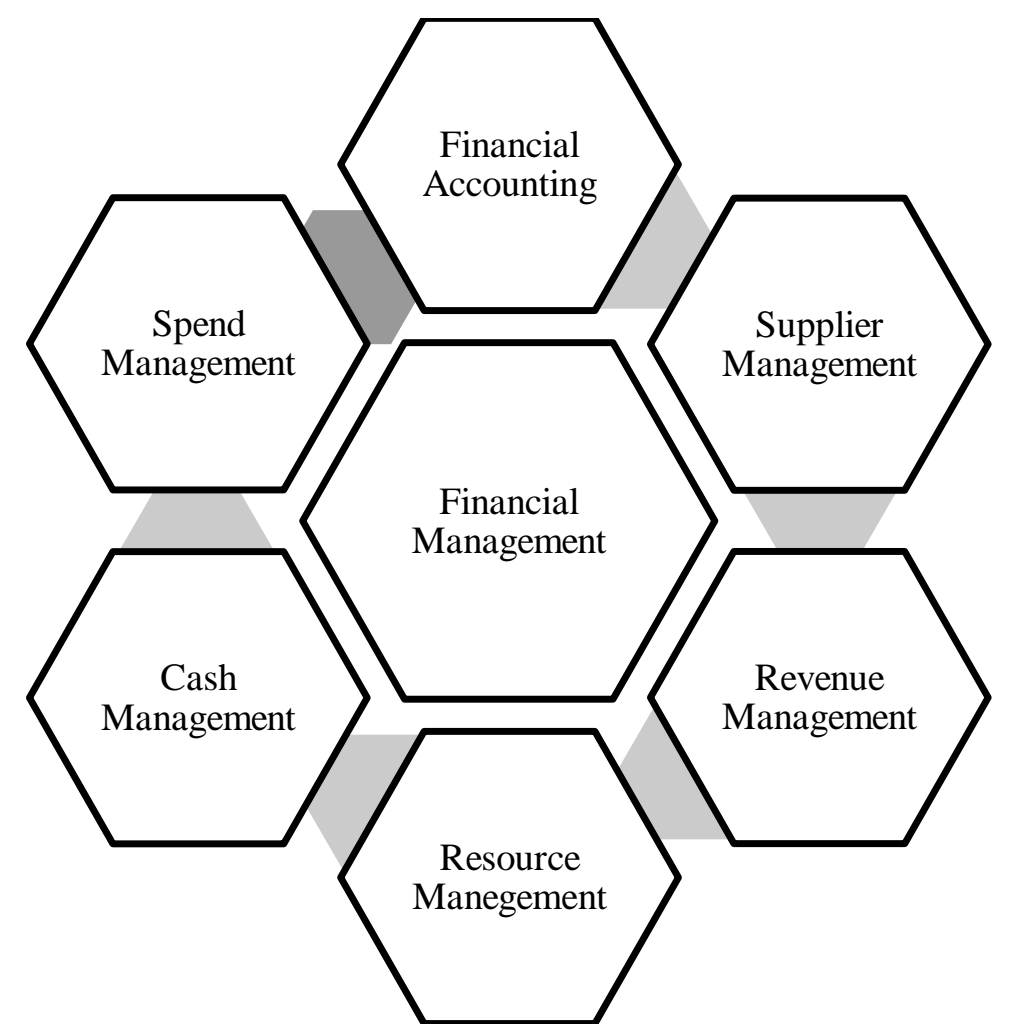

Figure 1 Financial Management System components

The application of extended econometric and economic modelling is a new aspect of pragmatic research as opposed to the other studies on the subject. Economic development of a country deals about the rate of production and investment which extends to growth in GDP of the country. Further in this paper we discuss about the methodology, structure of financial system, role of financial system in development of the economy, factors affecting the GDP growth and many more by taking reference from previous research study and articles published over it. [8]

\subsection{Methodology}


International Journal of Social Science and Economic Research

ISSN: 2455-8834

Volume:05, Issue:11 "November 2020"

\subsection{Neoclassical growth theory of economics}

The neoclassical growth theory introduced in late 1950 and 1960 by the two renowned economists Robert Solow (Nobel Prize winner in the field of economics) from America and J.E. Meade British economist. This neoclassical theory of growth puts focus on capital accumulation as an important deciding factor of economic development and its related saving decision. The theory suggests that short-term results are obtained by varying the number of labour and capital in the process of output. It also argue about the technological advancements has major impact on the economy and without it economic growth will not continue. It has three major factors labour, capital and technology.[11]

This theory conceives that the accumulation of capital within an economy is important for economic growth, and how people use the money. The interdependence between capital and labour influences the production. Although technology has improved labour productivity and labor production efficiency.

Thus neoclassical growth model uses this production function:-

$\mathrm{Y}=\mathrm{AF}(\mathrm{K}, \mathrm{L})$

Where,

$\mathrm{Y}=$ Gross Development Product (GDP)

$\mathrm{A}=$ Technology level

$\mathrm{K}=$ Capital Share

$\mathrm{L}=$ Number of unskilled labour.

Technology level contribution to economic growth in overall production is considered to be Solow residual, which means that total factor efficiency tests the increased output that is not adjudicated by differing factors, i.e. capital and labour.

The second important aspect carried out under this theory by Harrod-Domar growth model it says that planned saving and investments are always equal because of adjustments in prices while it does not account the probable demand of goods limiting economic development. Therefore this theory along with neo was called as classical. Growth efficiency of this model is achieved in the short run, as the rate of saving higher than the rate of capital accumulation is directly proportional.

Now under economic equilibrium we understand that the rate of growth of production is achieved by population growth and capital accumulation.

Del $\mathrm{Y} / \mathrm{Y}=\operatorname{Del} \mathrm{L} / \mathrm{L}=\operatorname{Del} \mathrm{K} / \mathrm{K}$ 
According to this earnings per capital and capital per worker is constant and therefore the capital will rise at the same rate as population.

$\operatorname{Del~Y/Y}=\operatorname{Del} \mathrm{L} / \mathrm{L}=\operatorname{Del} \mathrm{K} / \mathrm{K}=\mathrm{n}$

Neoclassical growth models result in decreasing returns to reproducible resources being the key factor behind the convergence. Rich countries with low capital-to-work ratios have high fixed capital goods, and therefore continue to expand at high levels. This propensity for low-income countries to develop at high levels is reinforced by extensions of neoclassical models that allow capital and technology to be mobilized internationally.[1]

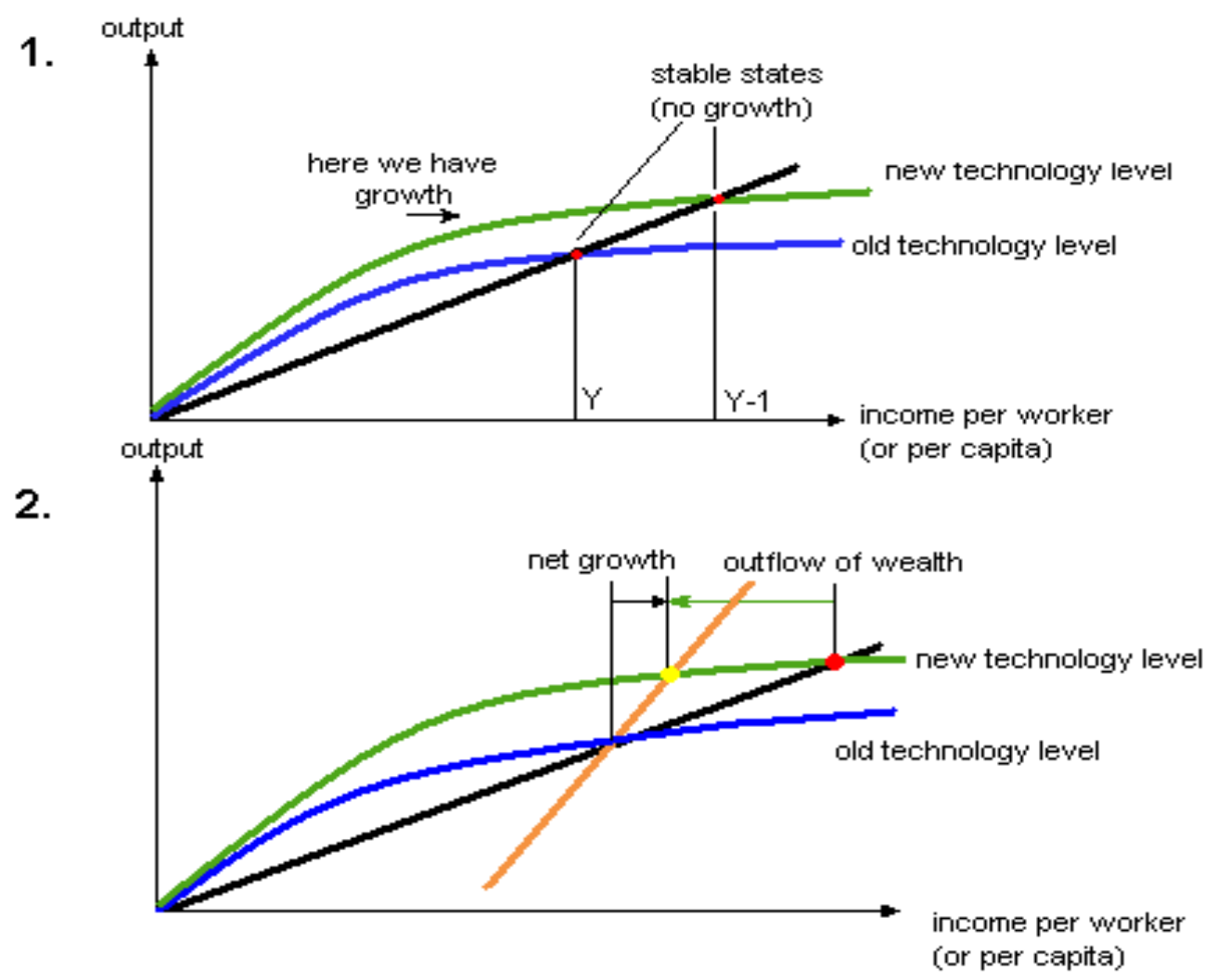

Figure 2. Neoclassical growth theory 


\subsection{Structure of financial system}

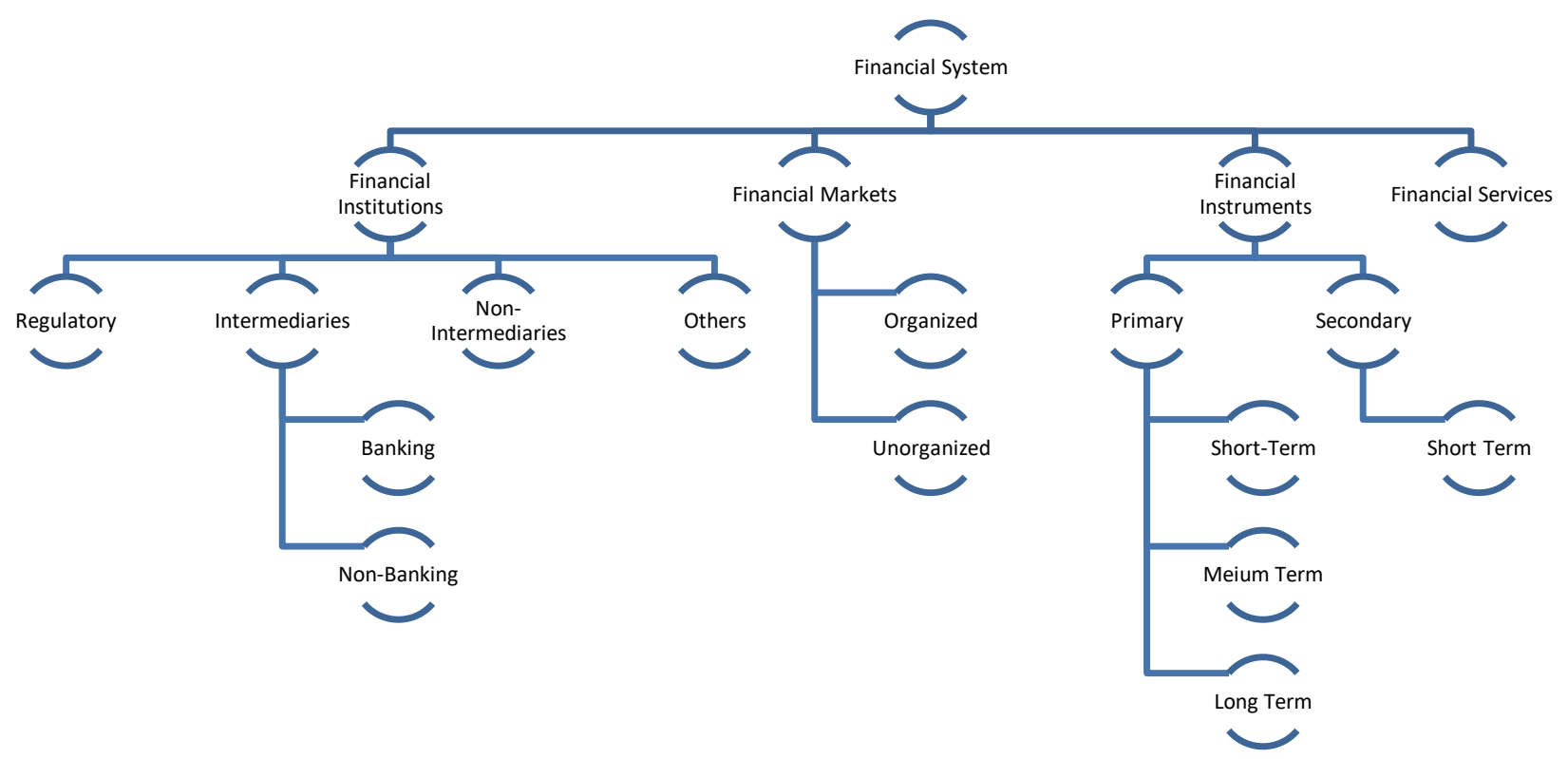

Figure 3 Hierarchy of Financial system

1. Financial Institution: A financial institution is a company that deals with financial and monetary activities, including deposits, loans, shares, and exchange of currencies. Financial companies serve a wide variety of financial services industry activities including banks, trusts, insurance firms, brokerages, and investment brokers.

2. Regulatory body: It is the organization which is responsible for governing and overseeing other financial institutions ' activities. Each country's central bank serves as a regulatory agency. For example, India's reverse bank, Rastra Bank of Nepal, etc.

3. Intermediators: These are those entities that receive funds directly from the surplus units as a deposit or premium, and offer them as a loan or investment to the deficit units. State, organisations, or people may be both units with surpluses and units with deficits.[2]

\subsection{Types of Financial Institutions}




\section{International Journal of Social Science and Economic Research}

ISSN: $2455-8834$

Volume:05, Issue:11 "November 2020"

\section{Commercial bank:}

These are associations of financial organizations that accept payments, make available accounting services, personal and mortgage loans, and offer basic financial products such as deposit credentials and savings accounts to small businesses and individuals.

Banks and similar type of business organization, such as credit union, facilitates with financial services like savings account, home mortgages, and many more commercial loans to customer. Bank also regulates the currency and provides a way to transfer money, serve payments via debit card, credit card, electronic transfers and one can exchange the currency.

\section{Investment Banks:}

Investment bank masters in large and complex transactions. It act as an intermediate between a security provider and act as broker or institutional investor financial advisor. Many investment banks operate at retail sector that serve individuals.

They help corporations to list a new share of stock in an initial public offering (IPO). It also studies the financial portfolio of the company for accuracy and to publish a brochure that gives details to the investors before purchase. Size is a strong point for investment banks as the vast it is, more the number of connections in markets, it will more likely to make greater percentage hike in profit.

3. Insurance companies:

A company that, in return for premium fees, offers coverage in the form of compensation arising from loss, harm, injury, care or hardship. The business estimates the probability of occurrence and then measures the cost of replacing (pay for) the loss to decide the amount of premium.

\section{Brokerage Firms:}

Brokerage companies are financial institutions that help you buy securities and sell them. Between buyer and seller they act as the middle man. You can either make your purchases and sales via mobile, internet or smartphone, depending on the type of brokerage firm you select. Brokerage companies typically charge a higher cost per purchase or sale order, with supported telephone orders.[14]

\subsubsection{Financial Markets:}

Often known as the stock market, the capital market is a mechanism designed to facilitate the acquisition and selling of financial instruments such as shares, bonds, debentures, etc. The stock market is made up of the issuing agency, investment banks, brokers, agents, and investors. [7] 


\section{International Journal of Social Science and Economic Research}

ISSN: $2455-8834$

Volume:05, Issue:11 "November 2020"

There are two kinds of finance markets: primary and secondary.

I. Primary market: Primary market is that form of security market where newly issued securities are exchanged. Throughout the primary security industry, investment banks play the key position by paying such fees to issue the new securities of different firms. Investment banker is an organization that plays mediators position between the business and the final investors. This lets the company gather the amount of capital needed by issuing their shares to the investors. Publishing company, investment banks and investors are main players in primary markets. It is an opportunity to investors to purchase the stock of company. Company's wealth comprises of sale in stock on the primary market.

Certain types of offers on prime stocks include private placement and preferential allocation. It helps companies to sell directly to bigger investor, such as hedge funds and banks, without having public stock. Where preferential allocation provides shares which are not available to the general public for selecting buyers at a special price.

II. Secondary market: It usually referred to as the purchasing securities "cash market," which comprises the New York Stock Exchange (NYSE), NASDAQ, and all other markets worldwide.

Whereas on liability market, a bond is supposed to pay the investors the full principal value at completion. Conversely, bondholders can sell secondary-market bonds for reasonable profit if rate of interest have dropped since their bond was issued, making it more attractive to other buyers because of its comparatively higher rate of coupons.

i. Auction Market: Both individuals and institutions involved in trading securities meet in one location and declare the prices they are prepared to buy and sell at. They are called bid rates and offer rates. The aim is for an open market to succeed by getting all parties together and making them announce their prices publicly. Thus, in principle, it is not necessary to try the preferable price of a good because the conjunction of buyers and sellers would cause commonly desirable prices to arise.

ii. Dealer Market: Contributors in the market are linked through networks. The broker maintain a secure catalogue, and are ready to transact with market contributors. Those dealers make money by changing the prices they purchase and they sell securities.

III. Capital market: It stations the saver's capital to those who can put it to profitable long-term use, including long-term corporate or government investments. Financial regulators such as the Securities and Exchange Board of India (SEBI), Bank of England (BoE), and Securities and Exchanges. [3]

IV. Money Market: 
International Journal of Social Science and Economic Research

ISSN: 2455-8834

Volume:05, Issue:11 "November 2020"

Money market is a short-term fund-providing economic feature. The money market deals with short term loans, typically for less than 365 days or equivalent. When money became an asset, this type of market is a part of the financial structure for assets involved in short-term trading, loaning, buying, and sale with one year or less original maturities. Most Western nations have several instruments on the capital market, including bills, commercial paper, banker acceptances, deposits, repurchase agreements, federal funds, and short-lived mortgage and asset-backed securities; It facilitates liquidity to the global economic system and capital markets, and is part of the large framework of the financial markets.

\subsubsection{Financial Securities:}

Protection, also known as financial asset, it is the legal document that specifies the right of investors to obtain potential prospective benefits under specified conditions, and to acquire or sell ownership interests. Financial securities are one of the easiest ways for the company to raise the amount of capital it needs. Several examples of financial instruments include common shares, preference stock, bonds, debentures, treasury bills, commercial papers, deposit certificates, etc. By general, financial instruments can be of a short and long-term type. Financial securities with a period of more than maturity are considered long-term securities and vice versa.

\subsubsection{Financial Services:}

Financial services include those offered by banks, finance firms, pseudo-bank financial firms, pension funds, mutual funds, investment banks, underwriters, etc.

\subsection{Interdependency of Financial System and Growth}

Performance for every nation depends on the growth in wealth that the nation experiences over a period of time. Economic development is about innovation and growth, and also about the size of the GDP in a nation. [10][12]

\subsection{Investment and savings}

In order to gain economic growth a nation needs more investment and growth. That can only happen where a saving has to be made. As, those savings are directed into productive capital in the form of investment.

\subsection{Capital market growth}

Any company requires two types of funds: fixed and labour fund. Fixed capital means investing in machinery or saying investing in secure assets. While working capital is used for sourcing and production of the raw material into final products. 
International Journal of Social Science and Economic Research

ISSN: 2455-8834

Volume:05, Issue:11 "November 2020"

Fixed capital is issued by the stock market by the bondholders and equity. Public and other financial organizations invest in these to gain a decent return with reduced threats.

Working capital market where businesses can get short-term loans by issuing various credit documentation such as bills, promissory notes etc.

The foreign exchange market helps buyers and traders to collect and raise funds for trade settlements. It also helps banks to borrow from and lend in different foreign currencies to specific types of customers. The business also provides the banks with ways to spend their shortterm unused funds to make profit.

\subsection{Security markets}

The financial system helps government and central governments by selling bills and bonds that carry competitive interest rates along with tax concessions to raise both short and long-term funds. The budget deficit is filled with only Indian stock-sector assistance. Therefore, the stock market, the money market along with the foreign exchange market and the government bond market allow companies, industrialists and governments to meet their credit requirements. The financial sector secures economic growth in this way.[5]

\subsection{Growth in infrastructure}

Economic expansion in every nation relies on the infrastructure facilities that are accessible to the government. The absence of major industries such as coal, energy, and oil will hinder the growth of other industries. The financial firms play a key role in providing financing to rising infrastructure businesses here. The private sector will be struggling to attract the massive capital needed to expand the infrastructure industries. Infrastructure companies have long been predominantly government-initiated in India. Today, however, with the economic liberalization agenda, more private companies came forward in scope of growth in infrastructure.

\subsection{Trade development}

The financial system helps in promoting national as well as foreign trade. Commercial companies fund traders, and the stock market assists with discounting financial instruments such as bills. Commercial banks support foreign trade by means of pre-shipment and post-shipment financing. By this way, the financial system gains not just the traders but also specific financial institutions. As a result of all these the development of the country is speeding up. They also award Letter of Credit to importers.

\subsection{Growth in employment}


The development of a financial system would create greater work prospects in the region. As a result of which demand increases, the stock market, which is part of the financial system, provides companies and consumers with working capital, giving them more incentives for employment. Despite the competition that is increasing in various markets, the services industry such as distribution, marketing etc. Numerous financial services such as leasing, factoring, commercial banking etc. can also create more employment. Trade growth also creates job opportunities in the region. Venture capital financing also generates new prospects for technobased companies and employment.

\subsection{Venture capital}

Economic growth of a country would be rapid as more companies are encouraged that need new technology and venture capital. Specific companies cannot get venture capital, because it calls for more threats. It is only through the financial system that more financial firms will subsidize a part of their investment funds to the construction of new ventures. And the financial organization helps to produce venture capital.[13]

\subsection{Fiscal management and economy control}

Through the financial firms the government will build a stable market so that there is no feeling of too much inflation or unemployment. The businesses should be given adequate security through the financial structure, so that their credit requirements can be met even during the problematic period. Through the financial system the government will build a stable market atmosphere so that there is no feeling of too much inflation or unemployment. [4]

\subsection{Uniformity in rate of interest}

The financial organizations are capable of achieving a constant rate of interest across the world, with free flow of funds between centres ensuring the availability of capital for all kinds of industries

\subsection{Investment of foreign capitals}

Finance framework serves stock market. A competitive stock market will attract both domestic and international funds. Investment will expand with more investment, and this will boost economic growth in a region.

\subsection{Financial intermediaries and economic development}

\subsection{Self-employment}

Growth in jobs is a symbol of economic growth. Financial intermediaries are creating more output and income in the country by providing funding for starting self-employment 
International Journal of Social Science and Economic Research

ISSN: 2455-8834

Volume:05, Issue:11 "November 2020"

programmes. In India, a variety of initiatives have been launched for self-employment schemes by banks following the nationalization of commercial banks.[3]

\subsection{Entrepreneurship development}

Various banks have successfully launched Business Growth programmes. At the district level, banks were initially creating job opportunities through the Lead Bank Scheme. Later, the Service Area Strategy was introduced in 1978, under which the banks were assigned some geographic areas to implement different economic programs for the growth of these areas.

\subsection{Rural development}

Under this system, financial intermediaries were funding citizens who were socially and economically disadvantaged by granting them loans for different commercial activities. One third of the loan would be a subsidy, with the remaining two-thirds of the loan bearing a lower interest rate under RBI's interest subsidy scheme. In this way, various economic policies are structured to boost the rural economy. Economic intermediaries promoted loans to businesses starting up in poor regions. Government has provided some concessions in the form of tax benefits to these industries and banks are providing cheap loans to attract more industries in the backward areas.

\subsection{Finance}

Financial intermediaries are offering housing loans as part of developing dwellings. Often, they have refinancing services for organizations like HUDCO (Housing and Urban Development Corporation). This has helped many people with fixed income groups to take advantage of the housing loan. Normally a bank offers 3-year gross net profit to a borrower or the cost of house, whichever is less under this facility.[12]

\subsection{Priority sector}

According to RBI guidelines, commercial banks must provide some percentage of their lending to the priority market, which consists of agriculture and its related operations, such as poultry, dairy, etc., cottage manufacturing, small-scale manufacturing, small-scale industries, and businesses.

\subsection{Conclusion}

The paper explores the empirical and analytical affiliation between the financial system and economic growth in an attempt to answer the question as to what degree of financial system development has a positive impact on GDP dynamics, and which way a financial system should evolve to sustain economic growth. A modern dimension of empirical analysis is the application 


\section{International Journal of Social Science and Economic Research}

ISSN: $2455-8834$

Volume:05, Issue:11 "November 2020"

of generalized econometric and economic modelling, including testing of non-linear associations between financial expansion and economic growth, measuring all financial variables levels and changes, and evaluating models based on a moving panel of contradictory results.

1). The dependency between financial system and rise in economy.

Growth in the stock market and in industry ensures a equal allocation of capital into the most profitable investments. The barriers to allocating and spending resources greatly improve the role of the financial firms in growth of wealth.

The financial services quality represents the honesty of the people who manage and maintain the financing systems and investment selections for the advantage of the investors.

2). Having large financial system does not mean to rise in economy and GDP of country.

A financial system's complexity is a sign of effectiveness, and a strengthened monetary market structure. Greater transparency contributes to lesser transaction costs. Complexity of a financial system means modern financial implements will improve savings and investment. Current wealth should consider the most suitable and lucrative asset projects that will make the most of the benefit of the stakeholders.

\section{References}

1. Economic Growth in a Cross Section of Countries Robert J. Barro The Quarterly Journal of Economics, Vol. 106, No. 2. (May, 1991), pp. 407-443 (used to study the growth model)

2. RAJAN, RAGHURAM G., and LUIGI ZINGALES. "FINANCIAL SYSTEMS, INDUSTRIAL STRUCTURE, AND GROWTH.” Oxford Review of Economic Policy, vol. 17, no. 4, 2001, pp. 467-482. JSTOR

3. BIS Working Papers No 165 Stress-testing financial systems: an overview of current methodologies by Marco Sorge Monetary and Economic Department December 2004

4.http://unepinquiry.org/wpcontent/uploads/2015/11/Effects_of_Financial_System_Size_and_Str ucture_on_the_Real_Economy.pdf

5. Próchniak, Mariusz \& Wasiak, Katarzyna. (2016). The impact of the financial system on economic growth in the context of the global crisis: empirical evidence for the EU and OECD countries. Empirica. 44. 10.1007/s10663-016-9323-9.

6. Puatwoe, J.T., Piabuo, S.M. Financial sector development and economic growth: evidence from Cameroon. FinancInnov 3, 25 (2017). https://doi.org/10.1186/s40854-017-0073-X

7. http://itheamc.blogspot.com/2017/12/structure-components-of-financial-system.html 
International Journal of Social Science and Economic Research

ISSN: 2455-8834

Volume:05, Issue:11 "November 2020"

8. Financial System Structure and Economic Development: Structure Matters by O. Emre Ergungor

9. https://accountlearning.com/role-of-financial-system-in-economic-development-of-a-country/

10. Leonardo Gambacorta, Jing Yang, KostasTsatsaronis Financial structure and growth

11. Neoclassical Theory of Economic Growth | India | Economics Article Shared by Ayesha $j$

12. https://accountlearning.com/role-of-financial-intermediaries-in-economic-development/

13. https://accountlearning.com/reason-for-slow-growth-of-venture-capital-companies-in-india/

14. Financial Deepening and Financial Inclusion by Bibek Debroy 